\title{
World Register of marine Cave Species (WoRCS): a new Thematic Species Database for marine and anchialine cave biodiversity
}

\author{
Vasilis Gerovasileiou₹, Alejandro Martínez§,|, Fernando Álvarez", Geoff Boxshall\#, William F. \\ Humphreys", Damià Jaume", Leontine E. Becking",', Guilherme Muricy”, Peter J. van Hengstum', \\ Stefanie Dekeyzer?, Wim Decock? , Bart Vanhoorne?, Leen Vandepitte? ${ }^{?}$, Nicolas Bailly ${ }^{\ddagger}$, , Thomas M. \\ $\|$ liffe $e^{\phi}$ \\ ‡ Institute of Marine Biology, Biotechnology and Aquaculture, Hellenic Centre for Marine Research, Heraklion, Greece \\ $\S$ Consiglio Nazionale delle Ricerche, Istituto per lo Studio degli Ecosistemi CNR-ISE, Verbania Pallanza, Italy \\ | Marine Biology Section, University of Copenhagen, Copenhagen, Denmark \\ I Colección Nacional de Crustáceos, Instituto de Biología, Universidad Nacional Autónoma de México, Ciudad de México, \\ Mexico \\ \# Department of Life Sciences, Natural History Museum, London, United Kingdom \\ a Department of Terrestrial Zoology, Western Australian Museum, Welshpool, Australia \\ «IMEDEA (CSIC-UIB), Mediterranean Institute for Advanced Studies, Esporles, Balearic Islands, Spain \\ " Marine Animal Ecology, Animal Science Group, Wageningen University, Wageningen, Netherlands \\ ${ }^{\wedge}$ Naturalis Biodiversity Center, Leiden, Netherlands \\ ` Departamento de Invertebrados, Museu Nacional, Universidade Federal do Rio de Janeiro, Rio de Janeiro, Brazil \\ ; Department of Marine Science, Texas A\&M University at Galveston, Galveston, United States of America \\ ? Flanders Marine Institute/Vlaams Instituut voor de Zee (VLIZ), Oostende, Belgium \\ ` FishBase Information and Research Group, Los Baños, Laguna, Philippines \\ \ Department of Marine Biology, Texas A\&M University at Galveston, Galveston, United States of America
}

Corresponding author: Vasilis Gerovasileiou (vgerovas@hcmr.gr)

Received: 09 Sep 2016 | Published: 13 Sep 2016

Citation: Gerovasileiou V, Martínez A, Álvarez F, Boxshall G, Humphreys W, Jaume D, Becking L, Muricy G, van Hengstum P, Dekeyzer S, Decock W, Vanhoorne B, Vandepitte L, Bailly N, lliffe T (2016) World Register of marine Cave Species (WoRCS): a new Thematic Species Database for marine and anchialine cave biodiversity. Research Ideas and Outcomes 2: e10451. doi: 10.3897/rio.2.e10451

\section{Abstract}

Scientific exploration of marine cave environments and anchialine ecosystems over recent decades has led to outstanding discoveries of novel taxa, increasing our knowledge of biodiversity. However, biological research on underwater caves has taken place only in a few areas of the world and relevant information remains fragmented in isolated publications and databases. This fragmentation makes assessing the conservation status of marine 
cave species especially problematic, and this issue should be addressed urgently given the stresses resulting from planned and rampant development in the coastal zone worldwide. The goal of the World Register of marine Cave Species (WoRCS) initiative is to create a comprehensive taxonomic and ecological database of known species from marine caves and anchialine systems worldwide and to present this as a Thematic Species Database (TSD) of the World Register of marine Species (WoRMS). WoRCS will incorporate ecological data (e.g., type of environment, salinity regimes, and cave zone) as well as geographical information on the distribution of species in cave and anchialine environments. Biodiversity data will be progressively assembled from individual database sources at regional, national or local levels, as well as from literature sources (estimate: $>20,000$ existing records of cave-dwelling species scattered in several databases). Information will be organized in the WoRCS database following a standard glossary based on existing terminology. Cave-related information will be managed by the WoRCS thematic editors with all data dynamically linked to WoRMS and its team of taxonomic editors. In order to mobilize data into global biogeographic databases, a Gazetteer of the Marine and Anchialine Caves of the World will be established. The presence records of species could be eventually georeferenced for submission to the Ocean Biogeographic Information System (OBIS) and constitute an important dataset for biogeographical and climate change studies on marine caves and anchialine systems.

\section{Keywords}

Marine caves, anchialine ecosystems, biodiversity, global species databases, biodiversity management

\section{WoRCS rationale and background}

\subsection{Rationale}

Scientific exploration of underwater cave environments over recent decades has led to outstanding discoveries of novel taxa, increasing our knowledge on biodiversity. Marine and anchialine caves are widely acknowledged as biodiversity reservoirs (Gerovasileiou and Voultsiadou 2012), harboring unique faunal elements including, among crustaceans for example, all members of the class Remipedia (Yager 1981), order Mictacea (Bowman et al. 1985), and families Macromaxillocarididae (Álvarez et al. 2006l) and Speleoithonidae (da Rocha and Iliffe 1991), representing relict lineages that will facilitate our understanding of the evolutionary history of encompassing taxa. Remipedes have recently been shown to be a sister group to hexapods, while the evolutionary relationships of many other anchialine taxa are still under study (von Reumont et al. 2011, Fanenbruck et al. 2004). Furthermore, a number of obligate cave-dwelling taxa show relict Tethyan distributions, extending across the Caribbean, Eastern Atlantic, Mediterranean, and Indian Ocean (e.g., Iliffe et al. 1983, Stock 1994). In contrast, other lineages of obligate anchialine taxa represent highly specialized lineages, nested within groups of deep sea or interstitial lineages and exhibiting 
unique adaptive features to cave life (Worsaae et al. 2004, Martínez et al. 2013, Martínez et al. 2014).

Marine and anchialine caves represent extreme environments due to their lack of light, paucity of organic nutrients, and often low levels of dissolved oxygen (Harmelin et al. 1985, lliffe and Kornicker 2009). In such habitats, it has been shown that chemoautotrophic bacteria can form the base of the food web (Pohlman 2011, Gonzalez et al. 2011), and other unique behavioral and physiological adaptations have been documented (Parzefall 1986, Bishop and Iliffe 2009). Furthermore, anchialine caves are characterized by stratified water masses harboring various ecological groups of organisms, dwelling respectively in the overlying freshwater layer, in the pycnocline, or in the underlying marine water (Sket 1996). Evidence has also been presented for how anchialine environments develop and respond to sea-level change over Holocene (van Hengstum et al. 2011, van Hengstum and Scott 2012) and interglacial (van Hengstum et al. 2009) timescales. Nevertheless, underwater cave biological research has been limited to only a few areas of the world and relevant information remains fragmented in isolated publications and databases. This fragmentation makes assessing the conservation status of marine and anchialine cave species especially problematic, and this issue is urgent given the stresses from global coastal urbanization.

\subsection{History}

The proposal for launching a World Register of marine Cave Species (WoRCS) originated from a question raised by V. Gerovasileiou who has conducted research in marine caves to N. Bailly as a taxonomic editor in WoRMS (for fishes) while they both worked for LifeWatch Greece Research Infrastructure in the Hellenic Centre for Marine Research (HCMR). The proposal was presented to the World Register of Marine Species (WoRMS) Steering Committee (SC) during its meeting at HCMR in Crete (8th June 2015). The SC agreed in principle to support this initiative. A proposal submitted to the LifeWatch Belgium grant mechanism for organizing WoRMS editor workshops was accepted in October 2015. A preworkshop meeting was attended by five of the eight WoRCS founding editors during the Third International Symposium on Anchialine Ecosystems hosted by the Universidad Autónoma de Yucatán (UADY), Mérida, México, in November 2015. The aim of the meeting was to refine the agenda and plan preparatory work for the Editor Workshop.

The first Editor Workshop of the WoRCS was held from 22 to 25 February 2016, at the Flanders Marine Institute (Vlaams Instituut voor de Zee) (VLIZ), Oostende, Belgium.

\section{Aims and scope of the World Register of marine Cave Species (WoRCS)}

\subsection{Aims}

The World Register of marine Cave Species (WoRCS) aims to create a comprehensive taxonomic and ecological database of species known from marine caves and anchialine 
environments worldwide. The assembled data will form a Thematic Species Database (TSD) of WoRMS (WoRMS Editorial Board 2016); technically, it is called a "context" in the WoRMS framework. The cave-related information will be managed by the WoRCS thematic editors in collaboration with the taxonomic editors of WoRMS, who manage the taxonomic content. The creation of this database will allow for an accurate assessment of the diversity and distribution of such faunas, and will provide information vital for evidence-based conservation.

\subsection{Ecological scope: types of environments}

There have been extensive discussions among specialists in order to characterize the different types of caves comprising anchialine ecosystems. Although a consensual definition was published (Stock et al. 1986), it has not been completely endorsed by the community, including some of the authors. In particular, defining what an anchialine cave is seems rather complex as there is an uninterrupted continuum of variation between strictly submarine and purely freshwater caves (Bishop et al. 2015). The essential point here is to reach a consensus about whether WoRCS should include data on inland freshwater caves and their species. It should be noted that WoRMS provides facilities to do so, and already manages a number of freshwater species, so there is no limitation from WoRMS' point of view. During the 1st Editor Workshop, it was decided to adopt a pragmatic approach, and to be as inclusive as possible, especially regarding opportunistic digitization and dissemination of any available data. This means that editors will integrate data based on their expertise and area of responsibility. If data are obviously outside the marine / brackish / anchialine scope of WoRCS, data may still be integrated, but various levels of filtering data for users' queries will be progressively implemented in WoRMS and Marine Regions (Claus et al. 2016) as necessary. Data from some purely freshwater underground systems have been already integrated during the workshop because they were readily available from one of the editors. These data may be interesting / necessary to explain the underground biodiversity around anchialine caves, and were endorsed during the workshop. The only restriction concerns the validation of the integration of species in WoRCS context (i.e., validation of the occurrence in a cave covered by WoRCS scope). However, purely freshwater species may increase significantly the amount of data in WoRCS. These data will remain under the responsibility of the editor who provided them, including data organization and appropriate quality control. It is anticipated that when data from the Freshwater Animal Diversity Assessment (FADA) (Balian et al. 2008) are more complete and disseminated, possibly through the Aphia platform (Vandepitte et al. 2015), this issue could be addressed in a more efficient way. The WoRCS Editor Group gives priority to saving legacy data, rather than constraining the scope, expecting that filter implementation will help to narrow down users' queries. Finally, it is also anticipated that the definition of anchialine cave could be refined through thorough analyses using aggregated data in WoRCS.

\subsection{Taxonomic scope}

The taxonomic scope of WoRCS covers primarily Protozoa and Animalia. Data entry on other kingdoms (e.g. Bacteria, Chromista, and Plantae) may be considered upon an 
opportunistic basis (e.g., for bacterial mats). Data associated with taxa at supra-species ranks will not be added to WoRCS until there is good evidence for the possible species identification. However, these data may be valuable, and a mechanism specific to WoRCS will be elaborated, e.g., through data files uploaded in the Integrated Marine Information System (IMIS) as sources.

\subsection{Occurrence status scope}

During the 1st Editor Workshop of the WoRCS there was a discussion if all epigean accidental visitors should be included in the taxonomic scope, especially in anchialine caves that are connected to freshwater systems where the water flow alone could be responsible for such occurrences (e.g., for cadavers) but also for accidental visitors reported from the entrance zone of submarine caves. This may significantly increase the number of species to document in WoRCS, beyond the Editorial Team capacities. The same responsible expertise approach as exposed in the subsection "2.2. Ecological scope: types of caves" above will be used; it could be also summarized like: keep the focus on data that are ecologically significant. The weakness of this approach is that rarely reported species could be eliminated while in the opposite case, with the potential accumulation of occurrence reports, we could extract some ecological signal. On the other hand, it was decided that only published information will be used (see Section 3 below), and literature sources summarizing these rare reports will be recorded in WoRCS.

\subsection{Geographic scope}

WoRCS aims at including data from all around the world. The discussions during the 1st Editor Workshop highlighted the difference of scientific research efforts in the various regions of the world. One consequence might be the apparent incompleteness of WoRCS, related to research effort bias. WoRCS has a role to promote research in understudied regions and will conduct a progressive geographic gap analysis.

\section{Main data sources}

The primary sources of information used for WoRCS are published species records, based on peer-reviewed literature sources. However, reliable unpublished records coming from offline databases, museum collections, field notes and the primary research of the WoRCS thematic editors will be also considered case by case. The WoRCS thematic editors are responsible for updating the content of the TSD by incorporating newly published records along with the new findings of their own research.

However, the main source of data in the initial upload into WoRCS was based on individual databases assembled by the WoRCS thematic editors and collaborators, as well as online global species databases, containing species lists from marine and anchialine caves and covering a broad taxonomic, geographic and temporal scale. A detailed description of the main database sources used by WoRCS is given below: 


\subsection{World Register of Marine Species (WoRMS)}

WoRMS already included a considerable number of cave-exclusive species and ca. 850 literature sources containing the string "cave" in their title, before the creation of the WoRCS TSD. All cave-related references were automatically incorporated into WoRCS by the WoRMS Data Management Team (DMT). Furthermore, the taxonomic editors of WoRMS have the possibility to assign cave species to the WoRCS context, in collaboration with the thematic editors of WoRCS, as was the case of the mysid Heteromysis (Olivemysis) ekamako, described from a marine cave in French Polynesia by Wittmann and Chevaldonné (2016) , which was simultaneously added to the World List of Lophogastrida, Stygiomysida and Mysida (Mees and Meland 2016) and to WoRCS.

\subsection{Database of Mediterranean marine cave biodiversity}

This database of Mediterranean marine cave biodiversity was created by V. Gerovasileiou and E. Voultsiadou, with technical assistance by $\mathrm{N}$. Bailly. It contains $>11,300$ records of 2,500 taxa reported from $>380$ caves in 15 Mediterranean countries. Data were derived from 322 scientific studies, but also from primary research in eastern Mediterranean marine caves. Preliminary results and a short description of the database have been published by Gerovasileiou and Voultsiadou (2014). All taxa in this database were cross-checked and taxonomically updated using WoRMS. The database has been already used as a source of information for studies on diversity of Porifera (Gerovasileiou and Voultsiadou 2012), marine cave biota of the eastern Mediterranean (i.e., Aegean and Levantine ecoregions) (Gerovasileiou et al. 2015), and non-indigenous species in Mediterranean caves (Gerovasileiou et al. 2016a).

\subsection{Subterranean marine cave fauna of the World}

This database has been created by A. Martínez and collaborators, including Thomas M. Iliffe, Brett C. Gonzalez, Diego Fontaneto and Katrine Worsaae, by compiling records published in the literature (e.g., Álvarez and lliffe 2008, Martínez García et al. 2009, Álvarez et al. 2015, Martínez et al. 2016), as well as unpublished field notes from the authors, collected from 1985 to 2016 (Boxshall and lliffe 1987, Kornicker and lliffe 1989, Kornicker et al. 2002, Wilkens et al. 2009, Schmidt-Rhaesa et al. 2013, Rubio et al. 2015). The database includes information from marine subterranean environments such as marine marginal caves, anchialine caves, freshwater caves occurring as part of more extensive anchialine systems, artificial wells and anchialine pools (e.g., Martínez et al. 2016). These systems include Yucatán Peninsula, Caribbean islands (e.g., Cuba, Jamaica, Hispaniola, Puerto Rico and Mona), the Bahamas, Turks and Caicos, Bermuda, Ascension, Macaronesia (mainly Canary Islands), Western Mediterranean, Balkans, Western Australia and several Indo-Pacific oceanic islands (e.g., Okinawa, Christmas Island, and Palau). At the current stage of development, the database contains ca. 9,500 records for ca. 1,200 caves and ca. 1,500 species, along with ecological (depth, penetration, salinity, habitat, light) and geological (age, rock, substrate) data. 


\subsection{Anchialine Caves and Cave Fauna of the World}

The "Anchialine Caves and Cave Fauna of the World" website by Thomas M. Iliffe includes species lists from anchialine caves of Bahamas, Bermuda and Yucatan. The purpose of the website is to document the diversity, significance and distribution of anchialine caves and cave animals.

\subsection{Database from Stygofauna Mundi}

During the BioFresh project, the FishBase Information and Research Group (FIN) was charged with digitizing the crustacean part of the book by Botoșăneanu (1986). Although primarily oriented to freshwaters ( $>2,300$ species for $>3,300$ locality records), a number of data records from marine caves were also included. This database was published under the BioFresh Portal. Further data encoding should focus on other phyla.

\subsection{SeaLifeBase and FishBase}

The "ECOLOGY" table in the SeaLifeBase already records about 60 species from caves, mainly from South America, which is complementary to the sources cited above. Some information is also recorded for fishes in FishBase (Froese and Pauly 2016).

\subsection{Aquatic cave fauna of Mexico and Central America}

This database was started by Fernando Álvarez in the 1990s in the context of several projects about groundwater fauna of the Yucatan Peninsula. It is mostly dedicated to Decapoda, and it records the occurrences of 52 anchialine species and up to 25 accidental species, in 226 localities of marine and anchialine caves. It contains taxonomical information, bibliographical references, specimen collection whereabouts, and conservation areas. The current location of the database is "Unidad de Informática para la Biodiversidad" (UNIBIO), but it will change and be moved with all collections of Universidad Nacional Autónoma de México (UNAM) under the Coordinación de Colecciones Universitarias Digitales (CCUD) project.

\subsection{Anchialine fauna of the Balearic Islands}

The list of 89 species occurring in anchialine caves of the Balearic Islands, compiled by Damià Jaume, was stored in a spreadsheet with the taxonomy, AphialD, habitat and remarks (Jaume and Gràcia 2006, Bauzà-Ribot et al. 2011, Gràcia and Jaume 2011, Cánovas et al. 2016). The selection of species follows a strict definition of anchialine species.

\subsection{Taxonomic Catalog of the Brazilian Fauna (TCBF):}

The Taxonomic Catalog of the Brazilian Fauna (Boeger et al. 2016 is an effort initiated in 2015 and coordinated by Walter A. Boeger, Hussam Zaher, José A. Rafael and Michel P. Valim, bringing together over 500 experts on different taxonomic groups to list all species of animals inhabiting the Brazilian territory and Exclusive Economic Zone. The list currently includes over 116,000 valid species, of which 85 are listed as cavernicolous, although most 
of them from freshwater caves. Information on the habitat and other ecological characteristics, however, is being uploaded progressively and is still missing for most species.

\subsection{Anchialine lakes and pools in the Indo-Pacific}

Anchialine lakes and pools in the Indo-Pacific have been the subject of research of several studies concerning predominantly sponges (e.g., Becking et al. 2013, Becking et al. 2014), ascidians (e.g., Monniot 2009), and crustaceans (e.g., Holthuis 1973, Fransen and Tomascik 1996). A considerable number of species records are also included in databases of NGOs that are active in the region and taxonomic lists of the Indonesian National Institute of Sciences (RCO-LIPI). This information will be integrated with checklists of algae, ascidians, crustaceans, mollusks, and sponges, produced during surveys of the Nat uralis Biodiversity Center (Leiden, the Netherlands) in anchialine systems in Indonesia, Vietnam and Palau.

\section{Current status of the WoRCS Thematic Species Database}

A dynamic webpage (Fig. 1) dedicated to the WoRCS Thematic Species Database (TSD) had been developed by the WoRMS DMT in collaboration with the WoRCS founding editors. It is hosted under the webpage of the WoRMS (URI: http://www.marinespecies.org/ worcs/) and the following citation for the current version of the database had been suggested (Gerovasileiou et al. 2016b):

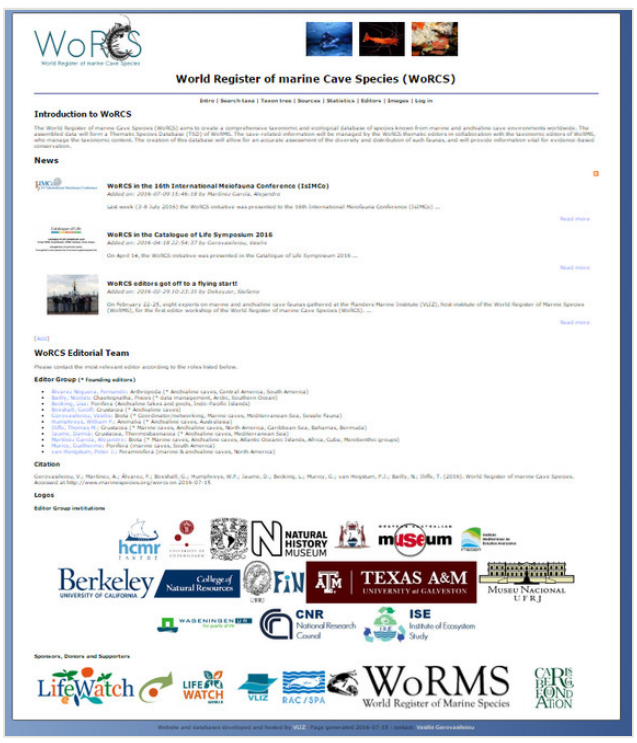

Figure 1.

The WoRCS webpage. 
- $\quad$ Gerovasileiou, V.; Martínez, A.; Álvarez, F.; Boxshall, G.; Humphreys, W.F.; Jaume, D.; Becking, L.E.; Muricy, G.; van Hengstum, P.J.; Bailly, N.; Iliffe, T.M. (2016). World Register of marine Cave Species. Accessed at http:// www.marinespecies.org/worcs on yyyy-mm-dd.

The WoRCS webpage presents basic information about the aims, the Editorial Team, literature sources and cave species, incorporating the basic taxonomic and search tools (e.g. Taxon Tree and Taxon Search) of Aphia (Fig. 2). The WoRCS Taxon Search engine provides various data filtering options that will be progressively enriched with several descriptors of the species' ecology and cave types, following a standard glossary (see Section 6 below) and thus enabling the proper harvesting and management of data by endusers.

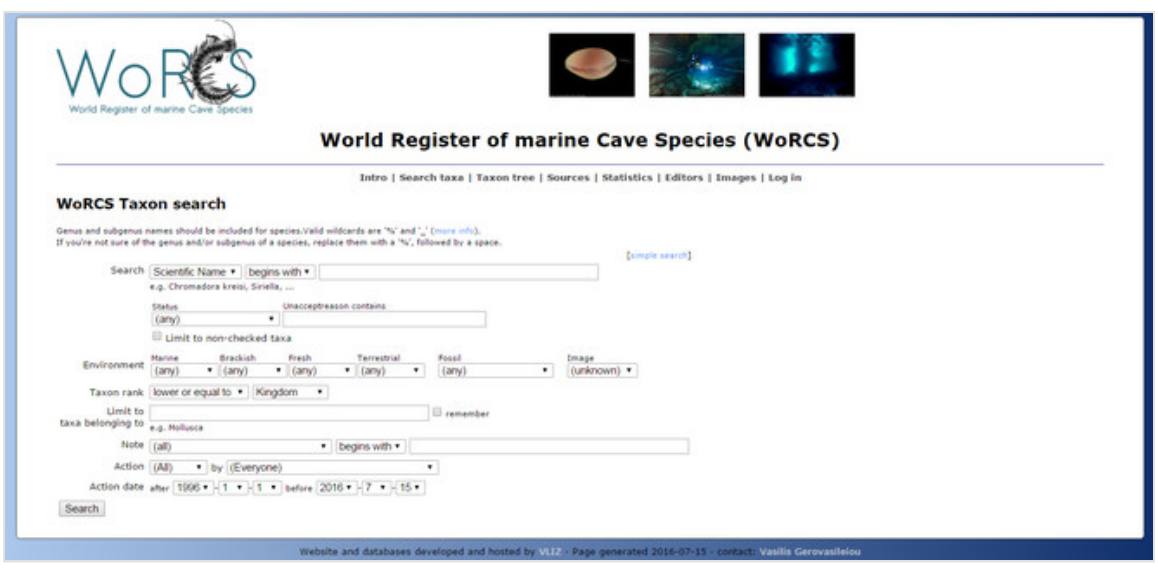

Figure 2.

The WoRCS search engine (advanced search option).

Descriptions of the content of the WoRCS database are also presented (Fig. 3). For instance, at present [05/08/2016] the database includes 3,208 taxa, of which 1,276 correspond to marine (M) and 216 non-marine (nM) accepted species. The majority of these records (568 $\mathrm{M}$ and $210 \mathrm{nM}$ accepted non-fossil species) are of Arthropoda, mostly crustaceans. The second species-rich phylum within the WoRCS context is Porifera (333 M species), followed by Nematoda (84 M species), Annelida (59 M and $3 \mathrm{nM}$ ), Chordata (49 $\mathrm{M}$ ), Cnidaria (39 $\mathrm{M}$ and $1 \mathrm{nM}$ species), Tardigrada (38 $\mathrm{M}$ species), Mollusca (33 $\mathrm{M}$ and 2 $\mathrm{nM}$ species) and Echinodermata (29 M species). The phyla Bryozoa, Brachiopoda, Cephalorhyncha (Kinorhyncha and Loricifera), Chaetognatha, Gastrotricha, Phoronida, Rotifera and Sipuncula are also represented, although with less than $20 \mathrm{M}$ species. Only few species of unicellular organisms have been so far included in WoRCS (1 M Ciliophora and $1 \mathrm{M}$ Foraminifera). The literature Source List of WoRCS currently includes 571 sources. 


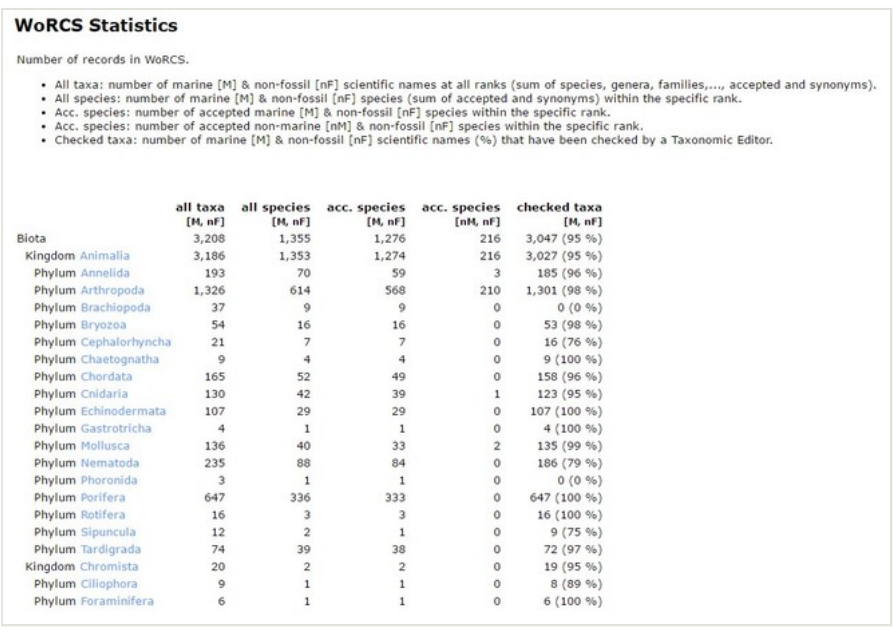

Figure 3.

Descriptions of the content of the WoRCS database.

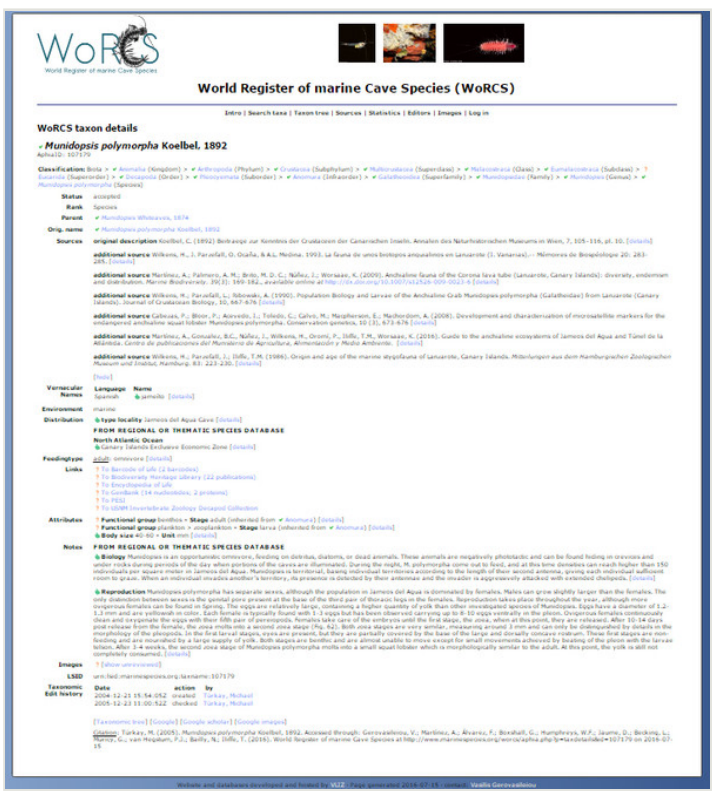

Figure 4.

The WoRCS taxon details page includes taxonomic information, references, vernacular names and distribution data, along with a series of attributes gathering information about morphology, biology, reproduction and ecology of each cave species.

In addition to the taxonomic information, the WoRCS database will be progressively enriched with information on the ecology and geographical distribution of cave species. The decapod species Munidopsis polymorpha Koelbel, 1892 is presented here as an 
example (Fig. 4): the presentation webpage of this species includes information on its taxonomical status, a list of synonyms and vernacular names, literature sources, distribution data, various attributes with ecological and biological information, notes with morphological descriptions and images. The images not only show the habitus and some details on the biology of the species (Fig. 5), but also the habitat or aspects relevant to the importance of the species for local societies (Fig. 6).

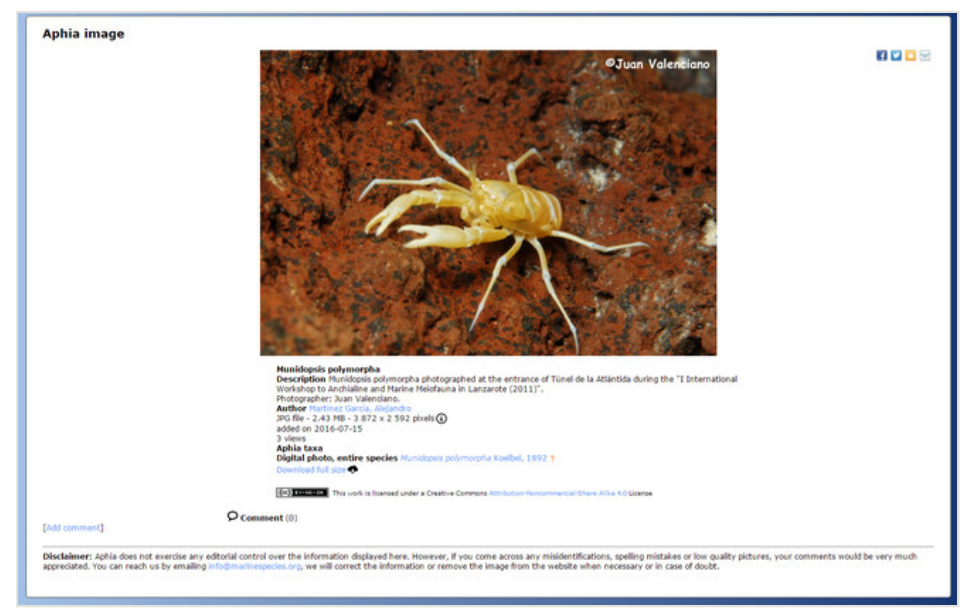

Figure 5.

Example of an image in WoRCS, showing the habitus and some aspects of the biology of a cave species.

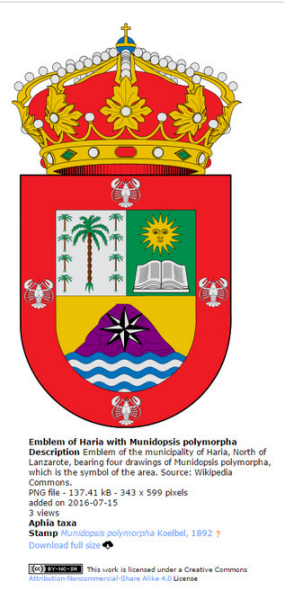

Figure 6.

WoRCS also includes images showing the significance of some cave species for local societies. 


\section{Gazetteer of marine and anchialine caves}

In order to generate occurrence data to be eventually served to the Ocean Biogeographic Information System (OBIS) and the Global Biodiversity Information Facility (GBIF), the WoRCS Editor Group will establish a gazetteer for the marine caves and anchialine systems of the world that will be coordinated by T.M. Iliffe. Thus, the species records available at WoRCS will be progressively georeferenced and layers for cave occurrence mapping will be created, providing an important dataset for the biogeographical and climate change studies on these ecosystems. The cave data will be integrated in the "Cave" object types in Marine Regions. Each marine cave or anchialine system will be described with 14 specific descriptors (see section 6.4 below). These descriptors will be searchable under the WoRCS interface through various filters. From the 14 descriptors, at least two will be mandatory for each cave or access point: (i) name or code, and (ii) coordinates or a locality. The coordinates will be provided only with three decimals of precision for possible conservation, privacy, and human security issues, especially regarding amateur and touristic diving. For instance, anchialine lakes in Indonesia are often being converted into aquaculture farms or holding basins for storing caught fish (Becking et al. 2011, Mangubhai et al. 2012). Initially only caves with species' records will be included in the gazetteer, although the creation of an additional but optional list for other caves will be evaluated in the future. The initial information included in the gazetteer will come from the database of some of the thematic editors (A. Martínez and V. Gerovasileiou), as well as different speleological societies (e.g., Quintana Roo Speleological Survey in Mexico).

Different mapping options, complementary to the mapping functionalities proposed by WoRMS and Marine Regions, such as enabling overlays with OBIS occurrence [see World Porifera database (Van Soest et al. 2016) distribution maps per species, e.g., for Spirastrell a cunctatrix Schmidt, 1868], will be also used (e.g., the Story Maps initiative by ESRI). Examples on Remipedia (i.e., Remipedia World Locations) created by B. Szukalski (ESRI) are restricted to the Editor Group (not available to the public yet).

\section{List of targeted data and associated vocabulary}

WoRCS will incorporate data on the biodiversity of marine caves and anchialine ecosystems of the world. In order to uniformly handle information within WoRCS, the editors compiled a list of targeted descriptors and a standard glossary based on existing terminology.

\subsection{Species known to occur in marine cave or anchialine ecosystems of the world}

\subsection{Ecological categorization of the species included in WoRCS}

The species included in the database will be categorized according to the following ecological descriptors: 


\subsubsection{Species salinity preference (multichoice)}

- Freshwater: species occurring at a salinity range of 0-0.5 ppt.

- Halocline: species preferably occurring at the halocline, probably using the organic matter and bacteria accumulated at that area.

- $\quad$ Brackish water: species occurring at a salinity range of 0.5-30 ppt.

- $\quad$ Saltwater: species occurring at salinities higher than $30 \mathrm{ppt}$.

\subsubsection{Ecological categories of taxa (after Culver and White 2012)}

- $\quad$ Stygobionts (sensu lato): obligatory aquatic cavernicoles only surviving in caves or similar subterranean habitats and usually showing a significant or total loss of vision and pigmentation. The term is used in a general sense to refer to cave-exclusive species.

- $\quad$ Stygophiles: facultative aquatic cavernicoles that can live and complete their life cycle within caves, but can also be found in suitable habitats outside caves. They usually present a certain degree of adaptation to the subterranean realm (e.g., reduction of eyes and pigmentation).

- Stygoxenes: aquatic animals which occur in caves, but, periodically return to the surface for food, e.g., certain mysids or fish.

- Accidental: aquatic organisms that enter a cave by chance (e.g., swept in by tidal currents or become disoriented and lost), but can only survive there for short periods of time.

- Undetermined: species with unknown ecological category.

\subsubsection{Light zones (after Culver and White 2012)}

- $\quad$ Daylight zone (LI): unshaded anchialine pools, totally exposed to sunlight.

- $\quad$ Cave entrance $(\mathrm{CE})$ : cave area that receives enough sunlight to permit the growth of algae.

- $\quad$ Semidark or Twilight zone (SD): cave area that receives limited sunlight, not enough to permit the growth of algae.

- Dark zone (DZ): cave area that has no light.

\subsubsection{Microhabitats, e.g., pools in caves, other physico-chemoclines (free text)}

\subsection{Geographical distribution in marine caves and anchialine systems}

Species records will be georeferenced using the coordinates from the Gazetteer of marine and anchialine caves.

\subsection{Type of environment}

Distinction between records from freshwater, anchialine and fully marine caves involves consideration of hydrographic data, especially salinity regimes (e.g., freshwater, pycnocline, marine water). 


\subsubsection{Water regime (multichoice)}

- Marine: a locality is categorized as hosting a marine water body when it contains a significant amount of water coming from the sea and mixing with comparatively short residence time.

- $\quad$ Freshwater: a locality is categorized as hosting fresh water body when it contains a significant amount of freshwater, either coming from the surface or from the groundwater aquifer.

- Anchialine: a locality is categorized as hosting an anchialine water body when it contains a significant amount of water with marine origin, but restricted exposure to open air, as well as negligible exchange with the open marine waters by diffusion with contiguous marine water bodies.

\subsubsection{Level of water mixing (for anchialine lakes and pools)}

- Holomictic: anchialine lakes and pools, which have a uniform temperature and density from top to bottom, allowing the lake waters to completely mix (Hamner and Hamner 1998, Dawson et al. 2009).

- Meromictic: anchialine lakes and pools, where layers of water do not intermix (Hamner and Hamner 1998, Dawson et al. 2009).

\subsubsection{Access point}

- Cave entrance: An opening from the surface into a natural underground or underwater hollow. For cavers, a cave is any natural hole, vertical (also known as potholes), horizontal, or a combination of both, which can be penetrated by humans (Romero 2009).

- Borehole / Well / artificial features: artificial entrance to the subterranean realm (e.g., Wilkens et al. 1986, Humphreys et al. 2013).

- $\quad$ Anchialine lakes and pools: water-filled depressions that can have various origins; they are surrounded by land without a surface connection to the adjacent sea (e.g., Por 1985, Wilkens et al. 1993) but only through porous rock, subterranean fissures or caves (Holthuis 1973, Hamner and Hamner 1998, Becking et al. 2011).

- Spring: any natural discharge of water from rock or soil onto the surface of the land or into a body of surface water (Monroe 1970, Botoșăneanu 1998, Stieglitz et al. 2013).

\subsubsection{Local terms}

- Ocean blue hole: in the Bahamas or Belize, a flooded sinkhole with a circular entrance extending beneath the seafloor (Mylroie et al. 1995)

- Inland blue hole: in the Bahamas or Belize, a flooded sinkhole with a circular entrance located inland from the coastline (Mylroie et al. 1995).

- Cenote: in the Yucatan and adjacent areas with Mayan influence, an inland sinkhole or steep walled natural well that extends below the water table (Monroe 1970).

- Grieta: in the Galápagos and Cuba, a vertical, seawater-flooded fissure formed by tectonic processes (Iliffe 1991). 
- Jameos: in the Canary Islands, a window into a lava tube formed either by collapse, incomplete closure of the roof of the cave, or by explosions during the formation of the cavity (Martínez et al. 2016).

- Casimba/Tanque: in Cuba, a sinkhole with a circular entrance above the sea level (Núñez-Jiménez 1984, Bozanic 1993).

- Vrulja: in Croatia, underground permanent streams discharging under the sea level (Surić et al. 2010).

- Lava tube: is a natural conduit formed by flowing lava which drained beneath the hardened surface of a lava flow (Monroe 1970).

\subsubsection{Rock type (from Field 1999)}

- Carbonate: a sedimentary rock composed principally of calcium carbonate (e.g., limestone, dolostone).

- Volcanic: rocks formed from magma from an erupting volcano.

- Other: rocks other than limestone or volcanic in nature.

\subsubsection{Oxygen concentration (from Kaiho 1994 ; multichoice)}

- High oxic: water bodies with dissolved oxygen concentrations of $>3.0 \mathrm{ml} / \mathrm{l}$

- Low oxic: 1.5 to $3.0 \mathrm{ml} / \mathrm{l}$

- Suboxic: 0.3 to $1.5 \mathrm{ml} / \mathrm{l}$

- Dysoxic: 0.1 to $0.3 \mathrm{ml} / \mathrm{l}$

- Anoxic: $<0.1 \mathrm{ml} / \mathrm{l}$

\subsubsection{Cave morphology (from Field 1999 and Palmer 1991)}

- Blind cave: a cave consisting of a comparatively short passageway that ends as a cul-de-sac.

- Tunnel: a cave consisting of a comparatively short passageway that opens to entrances at two or more ends.

- Pit: a vertical cave with negligible horizontal passages.

- Complex morphology: a cave consisting of arrays of intersecting passageways that form distinctive patterns.

- $\quad$ Artificial: a subterranean void created by humans (e.g., mines, tunnels, tombs, etc.).

\subsubsection{Submersion level (multichoice)}

- Submerged: a cave with at least some of its passageways extending below the water table.

- Semi-submerged: a cave in which at least some of its passageways extend at the level of the water table.

- Intertidal: a cave in which at least some of its passageways are directly exposed to and affected by the coastal tides. 


\subsubsection{Tidal amplitude (number)}

- Percentage (\%) of amplitude of the adjacent sea. In caves, this parameter is measured at the entrance (Holthuis 1973, Por 1985).

\subsubsection{Total length of the cave (number)}

\subsubsection{Maximum water depth (number)}

\subsubsection{Minimum water depth (number)}

\subsubsection{Position of the entrance from sea level (number)}

- Maximum depth for submarine entrances.

6.4.14. Remarks (free text to mention exceptions, additions, or other general comments)

\subsection{Other types of data}

- Editors must signal synonyms not yet in WoRMS to the respective taxonomic editors.

- $\quad$ Tickbox for non-indigenous species [link to the World Register of Introduced Marine Species (Pagad et al. 2016)].

- Tickbox for deep-sea species [link to the World Register of Deep-Sea Species (Glover et al. 2016)].

- $\quad$ Photographs (including the terms as defined by WoRMS).

- $\quad$ Clickable pdf describing the caves from various marine regions: to be managed as other references, with a link in Marine Regions.

- Maps and schemes of the caves: a protected repository will be created reserved for editors' use only. When used alone images in publications may have distinct copyrights than the entire pdf.

- $\quad$ Linking to molecular and phylogenetic databases.

- Information regarding the conservation status: IUCN categories are automatically updated directly from IUCN Red List database by WoRMS. However, national threat statuses are not recorded. Editors will identify websites or publications listing the national threat statuses to the WoRMS DMT for linking or batch uploading.

\section{WoRCS governance and policies (including data exchange)}

\subsection{Constitution of the Editorial Team}

The WoRCS Editorial Team is composed of thematic editors. Twelve of these editors will constitute the Editor Group that manages WoRCS, covering a broad taxonomic and geographical range. The WoRCS Editor Group will manage the membership in the team and in the group on consensus basis from any proposal or suggestion. No rules have been 
formally established for acceptance and exclusion of members. In case of difficulties, WoRCS will follow the current rules and practices in WoRMS, and will seek for advice from the WoRMS Steering Committee. The WoRCS Editor Group will select priorities for development of new tools in consultation with the WoRMS DMT and for data encoding. It will organize meetings, teleconferences (on demand by any of the Editor Group) and workshops, including an annual meeting to follow the yearly progress and to establish a working plan for the coming year.

Currently, only eleven thematic editors are in the WoRCS Editor Group (Table 1). All other thematic editors will support the overall initiative, provide/validate data and will be able to replace temporarily members of the Editor Group who may not be able to attend an annual meeting, or who have resigned from the Editor Group.

Table 1.

Current Editor Group of WoRCS (* founding editors) with its roles in terms of taxonomy, management, types of caves and geographic areas.

\begin{tabular}{|l|l|}
\hline Thematic Editor & Role \\
\hline Álvarez Noguera, Fernando* & Arthropoda (Anchialine caves, Central America, South America) \\
\hline Bailly, Nicolas* & Chaetognatha, Pisces (Data management, Arctic, Southern Ocean) \\
\hline Becking, Leontine E. & Porifera (Anchialine lakes and pools, Indo-Pacific Islands) \\
\hline Boxshall, Geoff* & Crustacea (Anchialine caves) \\
\hline Gerovasileiou, Vasilis* & Biota (Coordinator/networking, Marine caves, Mediterranean Sea, Sessile fauna) \\
\hline Humphreys, William F.* & Animalia (Anchialine caves, Australasia) \\
\hline lliffe, Thomas M.* & $\begin{array}{l}\text { Crustacea (Marine caves, Anchialine caves, North America, Caribbean Sea, } \\
\text { Bahamas, Bermuda) }\end{array}$ \\
\hline Jaume, Damià* & Crustacea, Thermosbaenacea (Anchialine caves, Mediterranean Sea) \\
\hline Martínez García, Alejandro* & Biota (Marine caves, Anchialine caves, Atlantic Oceanic Islands, Africa, Cuba, \\
& Meiobenthic groups) \\
\hline Muricy, Guilherme & Porifera (Marine caves, South America) \\
\hline van Hengstum, Peter J. & Amoebozoa, Foraminifera (Marine caves, Anchialine caves, North America) \\
\hline
\end{tabular}

Editors provide data and other documented expertise or assistance to WoRCS on a voluntary basis, as is the case for all the other taxonomic, geographic and thematic portals of WoRMS.

\subsection{Ownership, IPR, licensing and related issues}

WoRCS will follow the WoRMS rules (i.e. Creative Commons Attribution License, see Note to users). Like all editors in WoRMS, WoRCS editors were strongly recommended to sign the WoRMS Terms of Reference. 


\subsection{WoRCS specific policies}

The few policies listed below are not exhaustive and can be extended by the Editor Group as needed.

\subsubsection{Dissemination of datasets}

Unless restrictions of usage are mentioned, data that were published by any media are considered to have potential to be integrated in WoRCS and disseminated through WoRCS / WoRMS / Marine Regions, and additional signed agreements with Third Parties if any. However, a case by case approach is always possible to address complex situations.

\subsubsection{Different accuracy for locations for different users}

The dissemination of the precise location of access points (e.g. entrances) to marine caves and anchialine systems has to be carefully evaluated case by case for possible conservation, privacy, and human security issues (especially regarding amateur and touristic diving).

General principles regarding coordinates: published coordinates are stored in the Gazetteer as they are presented in the relevant publications. Previously unpublished coordinates are recorded in decimal degrees with only three decimals unless more restrictive constraints are notified, e.g., by owner of the cave or system, touristic exploitation companies, natural park managers, authors of papers (scientific, magazine, newspaper, etc.), administrative regulations at any level, etc.

\subsubsection{Data exchanges between WoRCS and editors' databases}

When editors will continue to maintain a separated database on their own with data that they provide to WoRCS, each editor will have to solve IPR issue separately with the WoRMS DMT. The usual issue of how to maintain the primary sources alive was raised by the WoRCS editors. One possibility is to use the connection with WoRMS as a leverage for fund raising, and to participate in projects. Technical issues may be raised, and may require the development of web services on the provider side, and client software on WoRMS side. This must be discussed on case by case basis. However, to facilitate further data exchanges, it is important that the personal databases keep the unique IDs used in WoRMS and Marine Regions.

\subsubsection{Illustrations (photos, drawings, schemas, etc.)}

General principle regarding photographs by WoRMS: Default usage of the Creative Commons Attribution-Noncommercial-Share Alike 4.0 License. 


\section{Dissemination and outreach}

Dissemination and outreach constitute priorities for the WoRCS Editor Group, aiming at the increase of global awareness on the diversity and significance of marine caves and anchialine systems. So far, the WoRCS initiative and its components have been or will be presented in following international symposia (see News section of the WoRCS webpage):

- $\quad 3^{\text {rd }}$ International Symposium on "Anchialine Ecosystems", 9-13 November 2015, Merida, Mexico

- $\quad$ Catalogue of Life Symposium 2016 "Management of taxonomic names: From global to local species lists; From local to global species lists", 14 April 2016, Hellenic Centre for Marine Research, Heraklion, Greece

- $\quad 16^{\text {th }}$ International Meiofauna Conference (IsIMCo), 3-8 July 2016, Hellenic Centre for Marine Research, Heraklion, Greece

- $\quad 1^{\circ}$ Congresso Nazionale Congiunto of the Italian Society of Ecology, the Italian Zoological Union and the Italian Society of Biogeography (SITE-UZI-SIB) on "Biodiversity: concepts, new tools and future challenges", 30 August - 2 September 2016, University of Milan Bicocca, Milano, Italy.

- $\quad 22^{\text {nd }}$ International Congress of Zoology and 87th Meeting of the Zoological Society of Japan joint events, 15-19 November 2016, Okinawa, Japan.

A Facebook group, entitled "WoRCS - Marine Cave Species" [405 members on 04/09/2016], and a Twitter account, entitled "WoRCS @CaveSpecies", managed by WoRCS thematic editors, have been created, with the aim to disseminate information on the marine and anchialine cave diversity of the world to the wide public.

\section{Strategic plan and perspectives}

During the 1st Editor Workshop that was held on February 2016 at the Flanders Marine Institute/ Vlaams Instituut voor de Zee (VLIZ), Oostende, Belgium, the WoRCS Editorial Team together with the WoRMS Steering Committee agreed on a strategic plan to ensure the development of the WoRCS database.

Every year, the Editor Group will discuss data encoding plans: (a) Gazetteer (b) by taxonomic group, (c) by geographic area, (d) on WoRCS in general. This discussion will take place in annual meetings, preferably organized back to back with other meetings/ conferences, at least at the beginning of the initiative. LifeWatch financially supports the organization of a number of editor-workshops, related to filling remaining gaps in WoRMS for specific taxa or themes (including groups that deal with marine and non-marine taxa).

The priorities for data encoding will be decided on the basis of a list of driving scientific questions, which will be reviewed by the Editor Group on the basis of communication with the Editorial Team during the year. However, data should be hypothesis-free encoded as much as possible, and then datasets can be assembled for answering scientific questions. 
All data currently held by the eight founding editors will be integrated in WoRCS as an early step of that process. Records of species will be progressively linked to ecological, morphological, genetic and phylogenetic traits. Taxonomic and geographic coverage by editors will be completed through the expansion of the Editorial Team (i.e., all taxa are monitored by an editor, as well as all areas with caves).

Several strategies were discussed in order to raise the standing of WoRCS in the biospeleology and marine biology scientific communities. Short and mid-term plans to engage the scientific community included: (a) the development of common projects on marine and anchialine caves, especially in areas rarely or not studied yet; (b) the initiation of a fellowship programme to engage young researchers, (c) projects that would use WoRCS data, and (d) the creation or participation to learned societies (e.g., Formal Society for anchialine studies and Expert group on anchialine studies in Biospeleology Society).

However, WoRCS is also intended to develop educational, citizen science and conservation activities, by creating products (e.g., maps, guides, courses) for the public, engage volunteers to encode data, and develop tools for MPA managers and the conservationist community. This could be achieved through different funding partnerships and mechanisms. During the workshop the editors created a list of potential partners to be contacted. In particular, each time that a project about caves is funded, a work package or module or deliverable about WoRCS should be included to employ students and young researchers for data encoding, or to facilitate new types of data, or new links to other einfrastructures and data tools.

\section{Acknowledgements}

The initiative was supported by LifeWatch, the E-Science European Infrastructure for Biodiversity and Ecosystem Research, through grants allocated by LifeWatch Belgium to the World Register of Marine Species (WoRMS) developed and maintained in VLIZ. LifeWatch Belgium provided the funds to VLIZ to host the 1st Editor Workshop through a competitive grant mechanism. LifeWatchGreece provided the staff time for the global workshop organization: V. Gerovasileiou and N. Bailly. LifeWatchGreece infrastructure (MIS 384676) is funded by the Greek Government under the General Secretariat of Research and Technology (GSRT), ESFRI Projects, National Strategic Reference Framework (NSRF). VLIZ provided the staff time for the workshop organization on site: W. Decock, L. Vandepitte, S. Dekeyzer, B. Vanhoorne; and Nathalie Keersebilck.

We thank the Marine Regions Data Management Team, Francisco Souza Dias and Nathalie De Hauwere for their introduction to the Marine Regions initiative and useful discussions about the integration of caves in the Marine Regions Gazetteer (MRG) during the 1st Editor Workshop and Bern Szukalski (ESRI) for his help with mapping options. We are grateful to Emmanouela Panteri (HCMR, LifeWatchGreece) and Gerald Hughes (Texas A\&M University at Galveston) for designing the WoRCS logo and Brett C. Gonzalez, Brian Kakuk (Bahamas Caves Research Foundation), Curt Bowen (ADM Foundation), Jill Heinerth (Into the Planet), Joerg Hess and Joris van der Ham who provided photographic 
material for the WoRCS Photogallery. VG, AM and NB would like to thank Christos Arvanitidis for his support and Eleni Voultsiadou, Brett C. Gonzalez, Diego Fontaneto and Katrine Worsaae for their contribution to the compilation of the individual databases on marine cave biodiversity. AM database was funded by the Carlsberg Foundation (Grant \# 2013_01_0779).

\section{References}

- Álvarez F, lliffe TM (2008) Fauna anquihalina de la península de Yucatán. In: Álvarez F, Rodríguez Almaraz GA (Eds) Crustáceos de México: Estado Actual de su Conocimiento. Universidad Autónoma de Nuevo León, 522 p. pp. [ISBN 978-970-694-482-5].

- Álvarez F, Villalobos JL, lliffe TM (2006) Macromaxillocarididae, a new family of stenopodidean shrimp from an anchialine cave in the Bahamas, with the description of Macromaxillocaris bahamaensis, n. gen., n. sp. Journal of Crustacean Biology 26: 366-378. DOI: $10.1651 / \mathrm{c}-2658.1$

- Álvarez F, lliffe TM, Benitez S, Brankovits D, Villalobos JL (2015) New records of anchialine fauna from the Yucatan Peninsula, Mexico. Check List 11: 1505. DOI: $\underline{10.155}$ $\underline{60 / 11.1 .1505}$

- $\quad$ Balian EV, Lévêque C, Segers H, Martens K (Eds) (2008) Freshwater animal Diversity Assessment. Developments in Hydrobiology. 198. Springer Netherlands, 640 pp. DOI: 1 0.1007/978-1-4020-8259-7

- Bauzà-Ribot MM, Jaume D, Fornós JJ, Juan C, Pons J (2011) Islands beneath islands: phylogeography of a groundwater amphipod crustacean in the Balearic archipelago. BMC Evolutionary Biology 11: 221. DOI: 10.1186/1471-2148-11-221

- $\quad$ Becking L, Renema W, Santodomingo N, Hoeksema B, Tuti Y, de Voogd N (2011) Recently discovered landlocked basins in Indonesia reveal high habitat diversity in anchialine systems. Hydrobiologia 677: 89-105. DOI: 10.1007/s10750-011-0742-0

- Becking LE, Cleary DF, de Voogd NJ (2013) Sponge species composition, abundance, and cover in marine lakes and coastal mangroves in Berau, Indonesia. Marine Ecology Progress Series 481: 105-120. DOI: 10.3354/meps10155

- $\quad$ Becking LE, de Leeuw C, Vogler C (2014) Newly discovered "jellyfish lakes" in Misool, Raja Ampat, Papua, Indonesia. Marine Biodiversity 45: 597-598. DOI: $\underline{10.1007 /}$ s12526-014-0268-6

- Bishop RE, lliffe TM (2009) Metabolic rates of stygobiontic invertebrates from the Túnel de la Atlántida, Lanzarote. Marine Biodiversity 39: 189-194. DOI: 10.1007/ s12526-009-0018-3

- $\quad$ Bishop RE, Humphreys WF, Kršinić F, Sket B, lliffe TM, Žic V, Moore WS, Cukrov N, Cukrov M, Boxshall GA, Pohlman JW (2015) 'Anchialine' redefined as a subterranean estuary in a crevicular or cavernous geological setting. Journal of Crustacean Biology 35: 511-514. DOI: 10.1163/1937240x-00002335

- Boeger WA, Zaher H, Rafael J, Valim MP (2016) Taxonomic catalog of the Brazilian fauna. http://fauna.jbrj.gov.br

- Botoșăneanu L (Ed.) (1986) Stygofauna Mundi. A faunistic, distributional, and ecological synthesis of the world fauna inhabiting subterranean waters (including the marine interstitial). E.J. Brill - Dr. W. Backhuys, Leiden, 740 pp. 
- $\quad$ Botoșăneanu L (Ed.) (1998) Studies in Crenobiology: The biology of springs and springbrooks. Backhuys Publishers, Leiden, $261 \mathrm{pp}$.

- Bowman TE, Garner SP, Hessler RR, Iliffe TM, Sanders HL (1985) Mictacea, a new order of Crustacea Peracarida. Journal of Crustacean Biology 5: 74. DOI: $\underline{10.2307 / 1548}$ 221

- Boxshall GA, lliffe TM (1987) Three new genera and five new species of misophrioid copepods (Crustacea) from anchialine caves on Indo-West Pacific and North Atlantic Islands. Zoological Journal of the Linnean Society 91: 223-252. DOI: $10.1111 /$ j.1096-3642.1987.tb01510.x

- Bozanic JE (1993) Preliminary investigations in anchialine caves of Cuba. In: Heine J, Crane N (Eds) Diving for Science. Proceedings of the 13th annual scientific diving symposium. American Academy of Underwater Sciences, Pacific Grove, CA

- Cánovas F, Jurado-Rivera J, Cerro-Gálvez E, Juan C, Jaume D, Pons J (2016) DNA barcodes, cryptic diversity and phylogeography of a W Mediterranean assemblage of thermosbaenacean crustaceans. Zoologica Scripta 00: 000-000. DOI: $10.1111 /$ zSC. 12173

- $\quad$ Claus S, De Hauwere N, Vanhoorne B, Souza Dias F, Oset García P, Hernandez F, Mees J (2016) MarineRegions.org. http://www.marineregions.org

- $\quad$ Culver D, White W (2012) Encyclopedia of Caves. Elsevier, Oxford, 654 pp.

- $\quad$ da Rocha C, lliffe TM (1991) Speleoithonidae, a new family of Copepoda (Cyclopoida) from anchialine caves on the Bahama Islands. Sarsia 76: 167-175. DOI: 10.1080/00364 827.1991.10413472

- Dawson MN, Martin LE, Bell LJ, Patris S (2009) Marine lakes. In: Gillespie R, Clague DA (Eds) Encyclopedia of islands. University of California Press, Berkeley, $1111 \mathrm{pp}$. [ISBN 9780520256491].

- $\quad$ Fanenbruck M, Harzsch S, Wagele JW (2004) From The Cover: The brain of the Remipedia (Crustacea) and an alternative hypothesis on their phylogenetic relationships. Proceedings of the National Academy of Sciences 101 (11): 3868-3873. DOI: $10.1073 /$ pnas.0306212101

- $\quad$ Field MS (1999) A lexicon of cave and karst terminology with special reference to environmental karst hydrology. U.S. Environmental Protection Agency, Office of Research and Development, National Center for Environmental Assessment, Washington Office, Washington, DC, 214 pp.

- $\quad$ Fransen CH, Tomascik T (1996) Parhippolyte uveae Borradaile. 1899 (Crustacea: Decapoda: Hippolytidae) from Kakaban Island, Indonesia. ZOOLOGISCHE MEDEDEELINGEN 70: 227-233.

- $\quad$ Froese R, Pauly D (2016) FishBase. www.fishbase.org

- Gerovasileiou V, Voultsiadou E (2012) Marine caves of the Mediterranean Sea: a sponge biodiversity reservoir within a biodiversity hotspot. PLoS ONE 7 (7): e39873. DOI: $10.1371 /$ journal.pone.0039873

- $\quad$ Gerovasileiou V, Voultsiadou E (2014) Mediterranean marine caves as biodiversity reservoirs: a preliminary overview. In: Langar $\mathrm{H}$, Bouafif $\mathrm{C}$, Ouerghi A (Eds) Proceedings of the first Mediterranean Symposium on the conservation of Dark Habitats. RAC/SPA, Tunis, 84 pp. [ISBN 978-9938-9574-1-9].

- Gerovasileiou V, Voultsiadou E, Issaris Y, Zenetos A (2016) Alien biodiversity in Mediterranean marine caves. Marine Ecology 37 (2): 239-256. DOI: $\underline{10.1111 /}$ $\underline{\text { maec. } 12268}$ 
- Gerovasileiou V, Chintiroglou C, Vafidis D, Koutsoubas D, Sini M, Dailianis T, Issaris Y, Akritopoulou E, Dimarchopoulou D, Voultsiadou E (2015) Census of biodiversity in marine caves of the eastern Mediterranean Sea. Mediterranean Marine Science 16 (1): 245-265. DOI: $10.12681 / \mathrm{mms} .1069$

- Gerovasileiou V, Martínez A, Álvarez F, Boxshall G, Humphreys WF, Jaume D, Becking L, Muricy G, van Hengstum PJ, Bailly N, Iliffe TM (2016) World Register of marine Cave Species. http://www. marinespecies.org/worcs

- Glover AG, Higgs N,, Horton T (2016) World Register of Deep-Sea species. http:// www.marinespecies.org/deepsea

- Gonzalez BC, lliffe TM, Macalady JL, Schaperdoth I, Kakuk B (2011) Microbial hotspots in anchialine blue holes: initial discoveries from the Bahamas. Hydrobiologia 677: 149-156. DOI: $10.1007 /$ s10750-011-0932-9

- Gràcia F, Jaume D (2011) La fauna aquàtica dels hàbitats anquihalins i dolçaquícoles de les cavitats balears. ENDINS 17: 257-268.

- Hamner WM, Hamner PP (1998) Stratified marine lakes of Palau (Western Caroline islands). Physical Geography 19: 175-220. DOI: 10.1080/02723646.1998.10642647

- Harmelin JG, Vacelet J, Vasseur P (1985) Les grottes sous-marines obscures: un milieu extrême et un remarquable biotope refuge. Téthys 11: 214-229.

- Holthuis LB (1973) Caridean shrimps found in land-locked saltwater pools at four IndoWest Pacific localities (Sinai Peninsula, Funafuti Atoll, Maui and Hawaii Islands): with the description of one new genus and four new species. ZOOLOGISCHE VERHANDELINGEN 128: 1-48.

- Humphreys G, Alexander J, Harvey M, Humphreys W (2013) The subterranean fauna of Barrow Island, north-western Australia: 10 years on. Records of the Western Australian Museum, Supplement 83 (1): 145. DOI: 10.18195/issn.0313-122x.83.2013.145-158

- $\quad$ lliffe TM (1991) Anchialine fauna of the Galápagos Islands. Topics in Geobiology. DOI: 1 $\underline{0.1007 / 978-1-4899-0646-511}$

- $\quad$ lliffe TM, Kornicker L (2009) Worldwide diving discoveries of living fossil animals from the depths of anchialine and marine caves. Smithsonian Contribution to the Marine Sciences 38: 269-280.

- $\quad$ Iliffe TM, Hart CW, Manning RB (1983) Biogeography and the caves of Bermuda. Nature 302: 141-142. DOI: 10.1038/302141a0

- Jaume D, Gràcia F (2006) Coves amb hàbitats anquialins de les Balears i coves amb hàbitats dolçaquícoles no litorals: catàleg espeleològic i faunístic. ENDINS 30: 71-82.

- Kaiho K (1994) Benthic foraminiferal dissolved-oxygen index and dissolved-oxygen levels in the modern ocean. Geology 22: 719. DOI: 10.1130/0091-7613

(1994)0222.3.c0;2

- $\quad$ Kornicker LS, Iliffe TM (1989) Ostracoda (Myodocopina, Cladocopina, Halocypridina) from anchialine caves in Bermuda. Smithsonian Contributions to Zoology 475: 1-88. DOI: $10.5479 /$ si.00810282.475

- $\quad$ Kornicker LS, lliffe TM, Harrison-Nelson E (2002) Ostracoda (Myodocopa) from Bahamian Blue Holes. Smithsonian Contributions to Zoology 616: 1-99. DOI: 10.5479/ si.00810282.616

- Mangubhai S, Erdmann M, Wilson J, Huffard C, Ballamu F, Hidayat NI, Hitipeuw C, Lazuardi M, Muhajir, Pada D, Purba G, Rotinsulu C, Rumetna L, Sumolang K, Wen W (2012) Papuan Bird's Head Seascape: Emerging threats and challenges in the global 
center of marine biodiversity. Marine Pollution Bulletin 64: 2279-2295. DOI: $\underline{10.1016 /}$ j.marpolbul.2012.07.024

- Martínez A, Di Domenico M, Worsaae K (2013) Evolution of cave Axiokebuita and Speleobregma (Scalibregmatidae, Annelida). Zoologica Scripta 42: 623-636. DOI: 10.11 11/zsc.12024

- Martínez A, Di Domenico M, Rouse G, Worsaae K (2014) Phylogeny and systematics of Protodrilidae (Annelida) inferred with total evidence analyses. Cladistics 31: 250-276. DOI: $10.1111 /$ cla.12089

- Martínez A, Gonzalez BC, Núñez J, Wilkens H, Oromí P, Iliffe TM, Worsaae K (2016) Guide of the anchialine ecosystems of Jameos del Agua and Túnel de la Atlántida (Lanzarote, Canary Islands). Cabildo de Lanzarote and Ministerio de Medio Ambiente, $308 \mathrm{pp}$.

- Martínez García A, Palmero AM, Brito MdC, Núñez J, Worsaae K (2009) Anchialine fauna of the Corona lava tube (Lanzarote, Canary Islands): diversity, endemism and distribution. Marine Biodiversity 39 (3): 169-182. DOI: 10.1007/s12526-009-0023-6

- Mees J, Meland K (2016) World List of Lophogastrida, Stygiomysida and Mysida. http:// www.marinespecies.org/mysidacea/

- Monniot F (2009) Some ascidians from Indonesian marine lakes (Raja Ampat Islands, West Papua). Zootaxa 2106: 13-40. DOI: 10.11646/\%25x

- Monroe WH (1970) A glossary of karst terminology. Geological Survey Water-Supply Paper 1899-K, US Government Printing Office, Washington DC, 29 pp.

- Mylroie J, Carew J, Moore A (1995) Blue holes: Definition and genesis. Carbonates and Evaporites 10 (2): 225-233. DOI: 10.1007/bf03175407

- Núñez-Jiménez A (1984) Cuevas y carsos. Editorial Científico-Técnica, Ciudad de La Habana, 431 pp.

- $\quad$ Pagad S, Hayes K, Katsanevakis S, Costello MJ (2016) World Register of Introduced Marine Species (WRIMS). http://www.marinespecies.org/introduced

- Palmer AN (1991) Origin and morphology of limestone caves. Geological Society of America Bulletin 103 (1): 1-21. DOI: 10.1130/0016-7606 (1991)103<0001:OAMOLC>2.3.CO;2

- Parzefall J (1986) Behavioural ecology of cave-dwelling fishes. The behaviour of teleost fishes. DOI: 10.1007/978-1-4684-8261-4_17

- Pohlman J (2011) The biogeochemistry of anchialine caves: progress and possibilities. Hydrobiologia 677 (1): 33-51. DOI: 10.1007/s10750-011-0624-5

- $\quad$ Por FD (1985) Anchialine Pools - Comparative Hydrobiology. Ecological Studies. 53. Springer, Berlin Heidelberg. [ISBN 978-3-642-70292-1]. DOI: $\underline{10.1007 / 978-3-642-70290}$ $\underline{-7 \_9}$

- Romero A (2009) Cave biology: life in darkness. Cambridge University Press, New York, 306 pp. [ISBN 978-0-521-82846-8]

- Rubio F, Rolán E, Worsaae K, Martínez A, Gonzalez B (2015) Description of the first anchialine gastropod from a Yucatán cenote, Teinostoma brankovitsi n. sp. (Caenogastropoda: Tornidae), including an emended generic diagnosis. Journal of Molluscan Studies 82 (1): 169-177. DOI: 10.1093/mollus/eyv049

- Schmidt-Rhaesa A, Rothe B, Martínez AG (2013) Tubiluchus lemburgi, a new species of meiobenthic Priapulida. Zoologischer Anzeiger - A Journal of Comparative Zoology 253 (2): 158-163. DOI: 10.1016/i.jcz.2013.08.004 
- $\quad$ Sket B (1996) The ecology of anchihaline caves. Trends in Ecology \& Evolution 11 (5): 221-225. DOI: 10.1016/0169-5347(96)20031-x

- $\quad$ Stieglitz TC, Beek Pv, Souhaut M, Cook PG (2013) Karstic groundwater discharge and seawater recirculation through sediments in shallow coastal Mediterranean lagoons, determined from water, salt and radon budgets. Marine Chemistry 156: 73-84. DOI: 10.1 016/. marchem.2013.05.005

- Stock J (1994) Biogeographic synthesis of the insular groundwater faunas of the (sub)tropical Atlantic. Hydrobiologia 287 (1): 105-117. DOI: 10.1007/bf00006900

- $\quad$ Stock JH, lliffe TM, Williams D (1986) The concept "anchialine" reconsidered. Stygologia 2: 90-92.

- Surić M, Lončarić R, Lončar N (2010) Submerged caves of Croatia: distribution, classification and origin. Environmental Earth Sciences 61 (7): 1473-1480. DOI: 10.100 7/s12665-010-0463-0

- Vandepitte L, Vanhoorne B, Decock W, Dekeyzer S, Verbeeck AT, Bovit L, Hernandez F, Mees J (2015) How Aphia -the platform behind several online and taxonomically oriented databases - can serve both the taxonomic community and the field of biodiversity informatics. Journal of Marine Science and Engineering 3 (4): 1448-1473. DOI: $10.3390 / \mathrm{jmse} 3041448$

- van Hengstum PJ, Scott DB (2012) Sea-level rise and coastal circulation controlled Holocene groundwater development in Bermuda and caused a meteoric lens to collapse 1600 years ago. Marine Micropaleontology 90-91: 29-43. DOI: 10.1016/ j.marmicro.2012.02.007

- van Hengstum PJ, Scott DB, Gröcke DR, Charette MA (2011) Sea level controls sedimentation and environments in coastal caves and sinkholes. Marine Geology 286: 35-50. DOI: 10.1016/j.margeo.2011.05.004

- $\quad$ van Hengstum PJ, Reinhardt EG, Beddows PA, Schwarcz HP, Gabriel JJ (2009) Foraminifera and testate amoebae (thecamoebians) in an anchialine cave: Surface distributions from Aktun $\mathrm{Ha}$ (Carwash) cave system, Mexico. Limnology and Oceanography 54: 391-396. DOI: 10.4319/lo.2009.54.1.0391

- Van Soest RW, Boury-Esnault N, Hooper JN, Rützler K, de Voogd NJ, Alvarez de Glasby B, Hajdu E, Pisera AB, Manconi R, Schoenberg C, Klautau M, Picton B, Kelly M, Vacelet J, Dohrmann M, Díaz M-, Cárdenas P, Carballo JL (2016) World Porifera database. http://www.marinespecies.org/porifera

- von Reumont BM, Jenner RA, Wills MA, Dell'Ampio E, Pass G, Ebersberger I, Meyer B, Koenemann S, Iliffe TM, Stamatakis A, Niehuis O, Meusemann K, Misof B (2011) Pancrustacean phylogeny in the light of new phylogenomic data: support for Remipedia as the possible sister group of Hexapoda. Molecular Biology and Evolution 29 (3): 1031-1045. DOI: $10.1093 / \mathrm{molbev} / \mathrm{msr} 270$

- Wilkens H, Parzefall J, lliffe TM (1986) Origin and age of the marine stygofauna of Lanzarote, Canary Islands. Mitteilungen aus dem Hamburgischen Zoologischer Museum und Institut 83: 223-230.

- Wilkens H, Parzefall J, Ocaña O, Medina AL (1993) La fauna de unos biotopos anquialinos en Lanzarote. Mémoires de Bióspéologie 20: 283-285.

- Wilkens H, lliffe TM, Oromí P, Martínez A, Tysall TN, Koenemann S (2009) The Corona lava tube, Lanzarote: geology, habitat diversity and biogeography. Marine Biodiversity 39: 155-167. DOI: 10.1007/s12526-009-0019-2 
- Wittmann K, Chevaldonné P (2016) Description of Heteromysis (Olivemysis) ekamako sp. nov. (Mysida, Mysidae, Heteromysinae) from a marine cave at Nuku Hiva Island (Marquesas, French Polynesia, Pacific Ocean). Marine Biodiversity available online: in press. DOI: $10.1007 / \mathrm{s} 12526-016-0522-1$

- WoRMS Editorial Board (2016) World Register of Marine Species. http:// www.marinespecies.org

- Worsaae K, Sterrer W, lliffe TM (2004) Longipalpa saltatrix, a new genus and species of the meiofaunal family Nerillidae (Annelida: Polychaeta) from an anchihaline cave in Bermuda. Proceedings of the Biological Society of Washington 117 (3): 346-362.

- Yager J (1981) Remipedia, a new class of Crustacea from a marine cave in the Bahamas. Journal of Crustacean Biology 1 (3): 328. DOI: $10.2307 / 1547965$ 